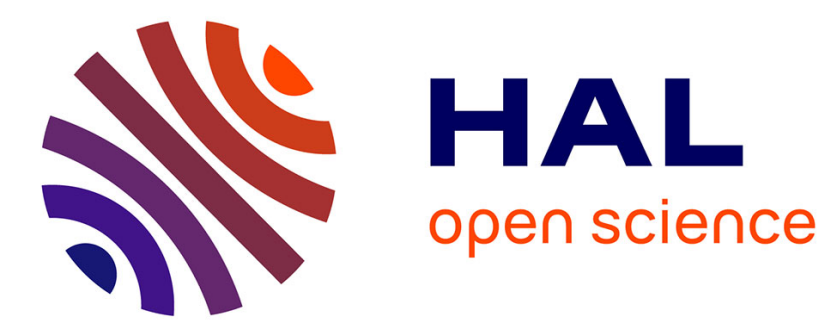

\title{
Plasma arc remelting of steels and nickel-based superalloys
}

\author{
N. Sparks, J. Young, L. Shaw, Thomas Johnson
}

\section{To cite this version:}

N. Sparks, J. Young, L. Shaw, Thomas Johnson. Plasma arc remelting of steels and nickel-based superalloys. Journal de Physique IV Proceedings, 1993, 03 (C7), pp.C7-883-C7-888. 10.1051/jp4:19937137 . jpa-00251757

\section{HAL Id: jpa-00251757 https://hal.science/jpa-00251757}

Submitted on 1 Jan 1993

HAL is a multi-disciplinary open access archive for the deposit and dissemination of scientific research documents, whether they are published or not. The documents may come from teaching and research institutions in France or abroad, or from public or private research centers.
L'archive ouverte pluridisciplinaire HAL, est destinée au dépôt et à la diffusion de documents scientifiques de niveau recherche, publiés ou non, émanant des établissements d'enseignement et de recherche français ou étrangers, des laboratoires publics ou privés. 


\title{
Plasma arc remelting of steels and nickel-based superalloys
}

\author{
N.C. SPARKS, J.M. YOUNG, L. SHAW* and T.P. JOHNSON
}

IRC in Materials for High Performance Applications, The University of Birmingham, Birmingham B15 2TT, U.K.

${ }^{*}$ Special Melted Products Limited, Atlas House, Attercliffe Road, Sheffield, S4 7UY, U.K.

\begin{abstract}
.
The IRC Plasma Arc Cold Hearth Remelting (PACHR) furnace has been used to produce 100mm and $150 \mathrm{~mm}$ diameter ingots of alloy 718, M50 bearing steel and G110 maraging steel from VIM/VAR feedstocks. These trials highlighted the importance of accurately controlling the level of the melt pool surface in the crucible in order to produce an acceptable ingot finish.
\end{abstract}

Chemical analysis of the ingots produced indicated no significant changes in the level of any element.

Cleanness of the ingots has been assessed using the Electron Beam Button Melt (EBBM) technique. The results obtained are encouraging but highlight the necessity for careful control of the plasma remelting process.

\section{INTRODUCTION.}

Plasma Arc Cold Hearth Remelting is seen as a potential alternative to the "conventional" steel and superalloy processing routes of vacuum arc remelting (VAR) and electroslag remelting (ESR). It offers some advantages such as the complete elimination of refractories from the processing, independent control of melting and solidification and suppression of alloying element loss by evaporation [1]. Additionally, it offers the possibility of melt refining as a result of density separation of inclusions present in the molten metal $[2,3]$.

In addition to consideration of possible refining effects, it must also be illustrated that the process can produce ingots of repeatable and acceptable surface qualities and segregation levels. To this end, three alloy compositions, M50 bearing steel, G110 maraging steel and 718 were processed in the IRC plasma furnace using a wide range of processing parameters in order to establish an operating envelope. Subsequently, cleanness and chemical analyses were carried out.

\section{EXPERIMENTAL PROCEDURE.}

All three alloys were supplied by Special Melted Products Ltd. in the form of surface machined or ground bar and specimens were taken from each for bulk and chemical analyses and electron beam button melt (EBBM) assessments. The nominal compositions of each of the feedstock alloys are given in table 1.

Table 1. Nominal compositions of feedstock alloys.

\begin{tabular}{|c|c|c|c|c|c|c|c|c|c|c|c|}
\hline & $\mathrm{Fe}$ & $\mathrm{Ni}$ & $\mathrm{Co}$ & $\mathrm{Mo}$ & $\mathrm{Ti}$ & $\mathrm{Al}$ & $\mathrm{C}$ & $\mathrm{O}$ & $\mathrm{Cr}$ & $\mathrm{V}$ & $\mathrm{Nb}$ \\
\hline $\mathrm{G} 110$ & 68 & 18 & 8 & 5 & 0.5 & 0.1 & 0.005 & 0.001 & - & - & - \\
\hline $\mathrm{M} 50$ & 89 & - & - & 4 & - & 0.05 & 0.8 & 0.001 & 4 & 1 & - \\
\hline 718 & 23 & 50 & - & 3 & 1 & 0.5 & 0.05 & 0.001 & 17 & - & 5 \\
\hline
\end{tabular}


The alloys were cast into either $100 \mathrm{~mm}$ or $150 \mathrm{~mm}$ water-cooled copper crucibles, the $100 \mathrm{~mm}$ ingot production serving primarily as an assessment of the effect of different melting parameters. The $150 \mathrm{~mm}$ ingots were then cast using the conditions deemed to be most suitable.

The IRC plasma arc cold hearth remelting (PACHR) furnace utilises two $150 \mathrm{~kW}$ transferred arc plasma torches, one dedicated to feedstock melting and maintenance of a liquid pool in the hearth, and the other for use in controlling solidification in the crucible and maintaining a clear notch between the hearth and crucible. Helium was used as the plasma gas and the chamber was maintained at a slight positive pressure with argon. Details of the furnace operation have been published elsewhere [4,5]. All torch and withdrawal control was accomplished using a Macintosh torch profiling control system. No dam (physical barrier) was used in the production of any of the ingots.

During production of all three $150 \mathrm{~mm}$ diameter ingots, the melt level was monitored using a system which relates arc voltage, and hence arc length, to the position of the melt surface in the crucible [6]. Every attempt was made to ensure that the melt level did not rise above its initial point during casting.

Bulk chemical analyses were carried out on specimens from both centre and edge positions at the top and bottom of the (PACHR) ingots. In addition, longitudinal and transverse slices were taken for the assessment of macrostructure.

The cleanness of feedstock and remelted materials has been assessed using the Electron Beam Button Melt (EBBM) process at the National Physical Laboratory, Teddington, U.K. All specimens for this assessment were taken from areas remote from the ingot surface and were prepared using a tungsten carbide tool. The characterisation of the inclusion cap formed at the surface of the EBBM button has been carried out using Scanning Electron Microscopy.

\section{RESULTS AND DISCUSSION.}

\section{Melting and Casting Observations.}

When casting both the 718 and G110 alloys, dross was evident at the surface of the hearth and also on the crucible top, having passed over from the hearth. This was not evident when processing M50 steel.

\section{Ingot Appearance.}

The surface finishes of the $150 \mathrm{~mm}$ diameter ingots were superior to those of the $100 \mathrm{~mm}$ diameter ingots of the same compositions in all cases. This was to be expected, as the $100 \mathrm{~mm}$ diameter ingots were produced in an attempt to optimise the melting conditions, and the $150 \mathrm{~mm}$ diameter ingots were produced using the melt level monitor mentioned above.

The difference in the surface quality of a representative $100 \mathrm{~mm}$ and $150 \mathrm{~mm}$ diameter ingot is shown in figure 1. The irregularities at the surface are known as "laps". The mechanism of their formation is discussed elsewhere [7] and the suggestion is made that an oscillation or "dither" superimposed on the downward motion of the ingot withdrawal is beneficial. This has not been found to be the case with these materials, trials on the $100 \mathrm{~mm}$ diameter ingots showing that better surface finishes are achieved with a simple, constant withdrawal. All of the $150 \mathrm{~mm}$ diameter ingots were produced in this way.

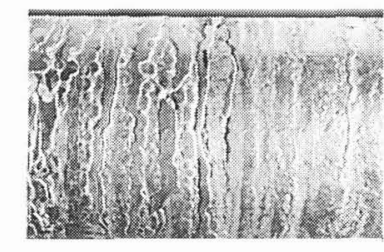

$100 \mathrm{~mm}$ diameter ingot $(\mathrm{G} 110 \mathrm{P} 1)$.

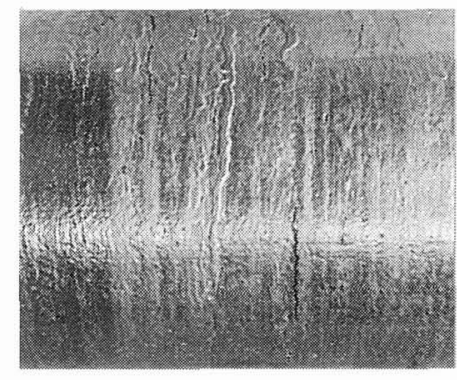

$150 \mathrm{~mm}$ diameter ingot (G110 P2)

Figure 1. Typical surface appearances of G110 maraging steel $100 \mathrm{~mm}$ and $150 \mathrm{~mm}$ diameter PACHR ingots. 
Casting experience has shown that a "splatter ring" will generally form on the copper crucible just above the level of the melt. It is imperative to ensure that the melt level does not rise into this region since, if it does;

a) it is in contact with a rough area likely to affect very adversely the ingot surface finish and

b) the splatter has been in intimate contact with the copper with the plasma plume passing over it repeatedly and, as such, may have high levels of copper contamination.

Maintenance of a constant melt level would be ideal, but fluctuations do occur as a result of the metal flow into the crucible from the hearth. In consequence, it is actually better to have a melt level that experiences a slight but constant fall.

The $150 \mathrm{~mm}$ diameter 718 ingot (718 P2) shows the very profound effect of melt level on ingot surface quality. The ingot and its corresponding withdrawal record are shown in figure 2 . The first $100 \mathrm{~mm}$ of this ingot were cast with a continuously falling crucible melt level. The level fell considerably more than is desirable, since the lower the melt level in the crucible, the more copper is exposed to the plasma arc and the higher is the risk of copper contamination. The ingot surface quality in this region is satisfactory. The melt level then stabilises briefly before rising for approximately $80 \mathrm{~mm}$ of cast ingot length. The ingot surface finish deteriorates noticeably in this latter period. The subsequent falling level does improve the surface finish slightly, but the fact that the casting is being done in a part of the crucible previously covered with splatter does diminish the positive effect of this falling level. The fluctuation in casting level has evidently further increased the splatter and hence roughness of the crucible, with the result that the last part of the ingot, cast with a rising melt level, exhibits the worst surface finish.

The $150 \mathrm{~mm}$ diameter M50 bearing steel ingot (M50 P2) shown in figure 3 was produced with the greatest fluctuations in casting level and its surface finish is significantly worse than the other materials. Conversely, the $150 \mathrm{~mm}$ diameter G110 maraging steel ingot (G110 P2) shown in figure 4 was produced with the most consistent fall in cast level and displays a surface finish far superior to the others.

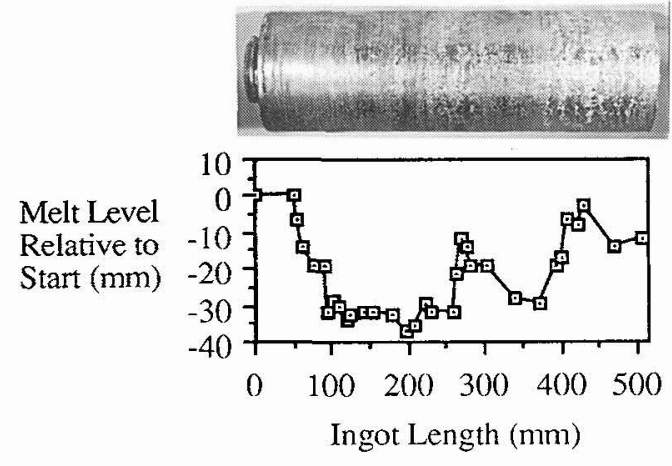

Figure 2. $150 \mathrm{~mm}$ Diameter 718 ingot and associated withdrawal trace. (718 P2).

\section{Macrostructure.}

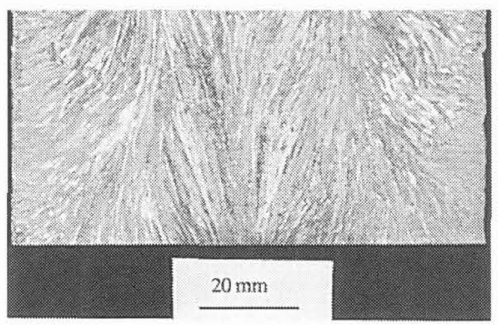

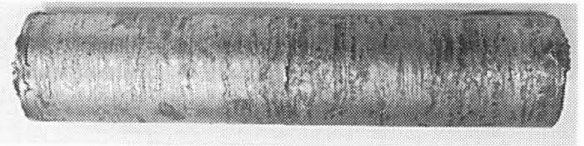

Figure 3. $150 \mathrm{~mm}$ diameter M50 ingot (M50 P2).

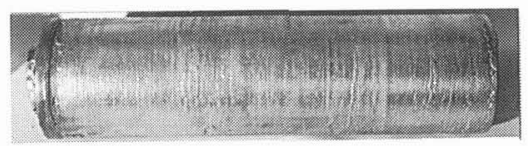

Figure 4. $150 \mathrm{~mm}$ diameter $\mathrm{G} 110$ ingot (G110 P2).

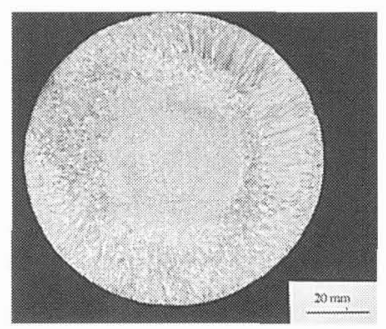

Figure 5. Macrostructures of $100 \mathrm{~mm}$ diameter G110 maraging steel ingot (G110 P1). 
Typical PACHR maraging steel macrostructures are shown in figure 5. On both longitudinal and transverse specimens, melt pool asymmetry is obvious. This is largely due to the asymmetry of both the torch movement and the melt flow from the hearth into the crucible.

The torch spends a relatively longer time near the hearth/crucible notch as a result of the patterns used to clear the notch. In addition, the heat input from the melt flowing into the crucible is obviously higher in the notch region. This effect is reduced to some extent by the electromagnetic stirring and stirring action of the plasma plume.

\section{Chemical Composition.}

No significant compositional differences were detected in any of the $150 \mathrm{~mm}$ diameter ingots as compared to the respective feedstocks. In addition, no compositional variations were detected from centre to edge in any of these ingots.

The levels of oxygen in the remelted materials were of particular interest due to their effect on material cleanness. The results obtained indicated no significant differences, all of the changes being within the range of experimental variability. In stating this it is worth, however, stressing the high level of processing of the feedstock material which was in the VIM/VAR condition. Large changes in oxygen level are therefore unlikely. As an indication of the integrity of the furnace atmosphere, no nitrogen pick-up was detected.

\section{Cleanness.}
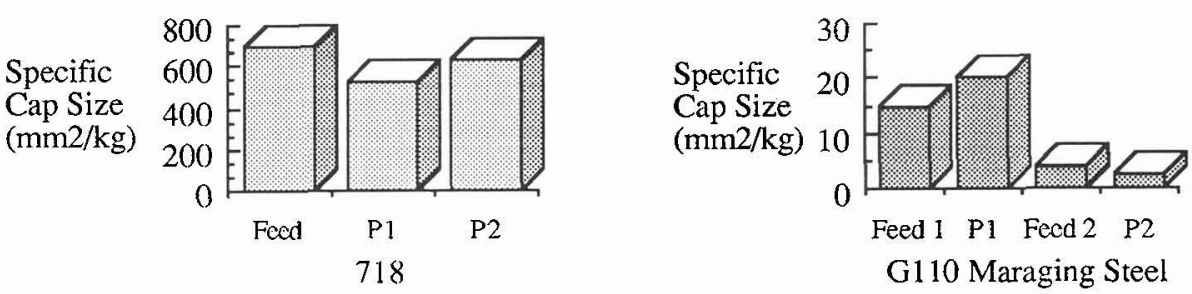

Figure 6. Specific cap sizes for 718 and G110 maraging steel feedstocks and plasma remelted material.

The 718 inclusion cap consists of a layer of titanium nitrides on which are present a distribution of oxide particles. A reduction in cap size can therefore be considered to be an improvement in cleanness. Both the $100 \mathrm{~mm}$ and $150 \mathrm{~mm}$ diameter plasma remelted ingots (718 P1 and $718 \mathrm{P} 2$ respectively) have experienced a reduction in cap size. The most interesting observation, however, is the apparent decrease in average nitride size in $718 \mathrm{P} 2$ relative to the feedstock (see figure 7 ). This is not evident on studying $718 \mathrm{P1}$.

Two different G110 maraging steel feedstocks were used, one was cast into a $100 \mathrm{~mm}$ diameter crucible (G110 P1) and the other into a $150 \mathrm{~mm}$ diameter crucible (G110 P2). An increase in cap size is indicated for G110 P1 and a decrease for G110 P2. The changes are, however, rather small.

(a)

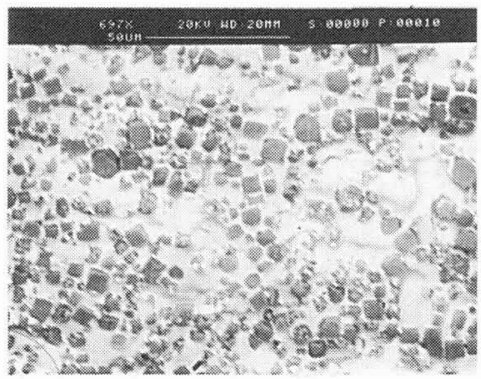

(b)

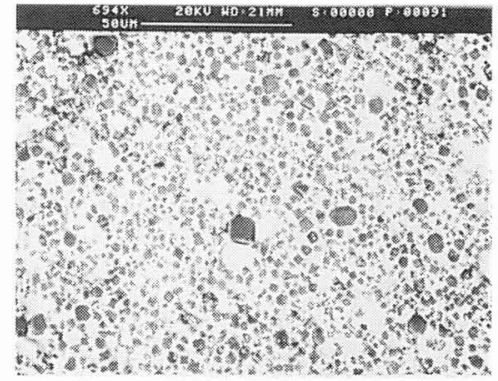

Figure 7. SEM backscattered electron micrographs of nitrides on EBBM cap from a) 718 feed b) 718 P2.

Preliminary results indicate that plasma processing has done little to alter the level of oxide inclusions in either size or number in the 718 material. Oxides of approximately $120 \mu \mathrm{m}$ have been observed in the feed and remelted material. These oxides primarily contain aluminium, but have traces of titanium, calcium and silicon present also. It is, perhaps, not surprising that little change has been effected in terms of the numbers and size of the inclusions since, without the use of an effective method of preventing floating inclusions 
passing over into the crucible, plasma arc remelting has lost its primary refining method. There are, however, considerable difficulties associated with the use of such a barrier, such as maintaining a melt pool underneath the barrier itself, increased exposure of copper to the plasma and, not least, the lack of confidence that the process will always work in the same way.

The EBBM button for maraging steel ingot G110 P1 has significantly more oxides on the cap than its feedstock material. The two inclusion caps are shown in figure 8. However, ingot G110 P2 appears to have a lower number of oxides on its EBBM button cap than does its feedstock. This result indicates the necessity for careful control of the process. It is suspected that, since no method of retaining floating inclusions in the hearth was used, a "raft" floating at the surface which then passed over into the crucible may have produced this effect - certainly there is visual evidence of inclusions passing over into the crucible. An EDAX trace for a typical inclusion present in G110 maraging steel is shown in figure 9, indicating that the inclusions are primarily aluminium oxides.

a)

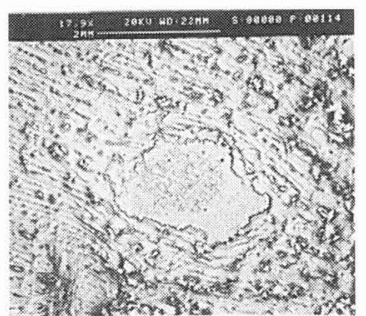

b)

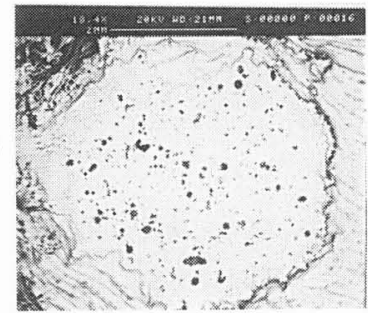

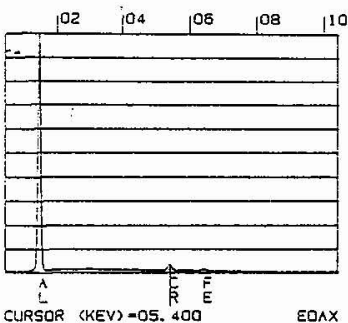

Figure 9. EDAX trace for typical inclusion in G110 maraging steel.

Figure 8. SEM BSE images for EBBM buttons of (a) Feed 1 (b) P1.

A graph illustrating the effect of plasma processing on the level of oxides present on the surface of EBBM buttons of M50 bearing steel is shown in figure 10.

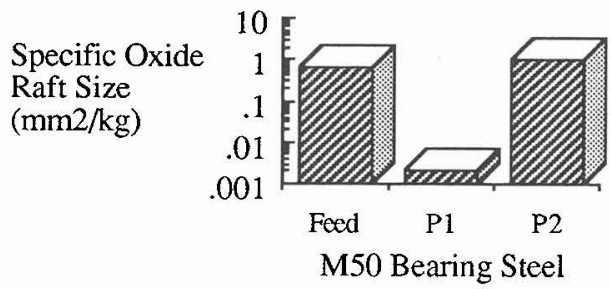

Figure 10. Graph showing oxide raft size for feedstock and PACHR M50 bearing steel.

It is evident that whilst the M50 100mm diameter remelt ingot (M50 P1) has experienced an improvement in cleanness of three orders of magnitude, the cleanness of the $150 \mathrm{~mm}$ diameter M50 remelted ingot (M50 P2) has deteriorated somewhat. The possible reasons for this become a little clearer on studying SEM micrographs of the oxide inclusion rafts present on the feedstock, M50 P1 and M50 P2 EBBM buttons. These are shown in figures 11,12 and 13 respectively.

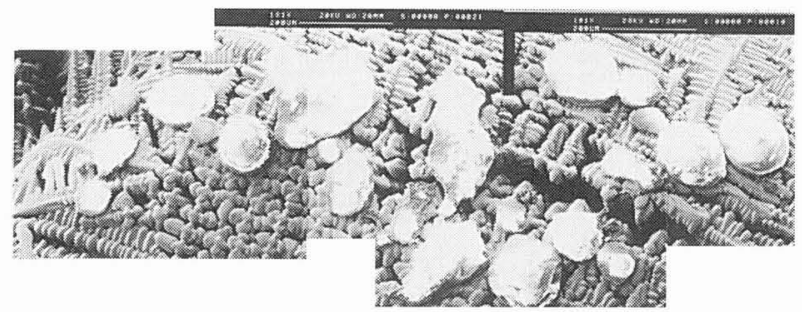

Figure 11. SEM secondary electron image of oxide raft on M50 feedstock material EBBM button.

It is obvious that the feedstock has a significant number of particles in excess of $200 \mu \mathrm{m}$. M50 P1 is very clean and exhibits only one particle of $-50 \mu \mathrm{m}$ size as shown in figure12. M50 P2 exhibits a very large particle of $\sim 750 \mu \mathrm{m}$ and an adjacent particle of $\sim 350 \mu \mathrm{m}$ size (figure 13). The surface appearance of these 
particles suggests a degree of agglomeration. Since the oxides consist of predominantly $\mathrm{Al}$ and $\mathrm{Ca}$ in this alloy, as shown in figure 14, and will therefore have a relatively low melting point, it is feasible that melting and agglomeration has occurred in either the PACHR or EBBM process, producing some much larger particles which, when detected, give the appearance of reduced cleanness.

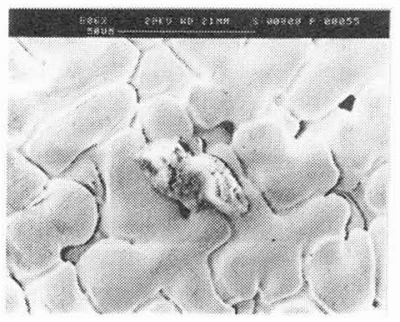

Figure 12. SEM BSE image of oxide inclusion raft on M50 P1 EBBM button.

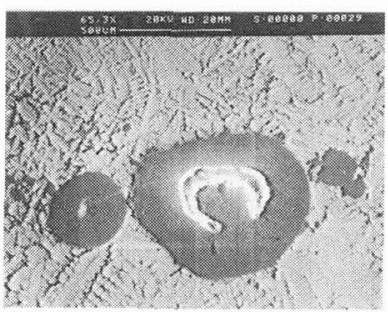

Figure 13. SEM BSE image of oxide inclusion raft on M50 P2 EBBM button.

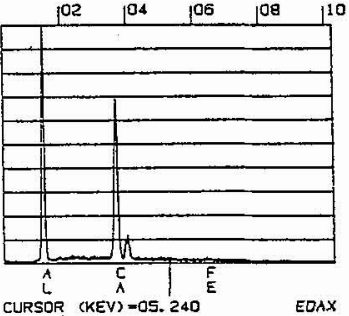

Figure 14. EDAX trace for typical oxide inclusion found in M50 bearing steel.

\section{CONCLUSIONS.}

(i) PACHR has produced sound ingots of acceptable homogeneity in 718, G1 10 maraging steel and M50 bearing steel materials.

(ii) Acceptable ingot surface finishes have been achieved, the results obtained emphasising the importance of accurate control of the crucible melt level during casting.

(iii) A reduction in the average size of nitrides present in PACHR 718 material relative to its feedstock material has been indicated.

(iv) Reduced oxide levels have been indicated in one M50 steel ingot by use of the EBBM test. However, other results have emphasised the importance of careful control of all melting parameters to achieve cleanness.

\section{ACKNOWLEDGMENTS.}

The following are gratefully acknowledged; The SERC for the Plasma Melting facility, the plasma melting team at the IRC for their hard work in remelting the materials, Special Melted Products Ltd. for funding and materials supply, Rolls Royce plc. for experimental facilities and guidance and The National Physical Laboratories for EBBM facilities.

\section{REFERENCES.}

(1) ESCHENBACH R.C and HERMAN G., "Plasma Melting of Reactive Metals" Proc. of the 1984 Vacuum Metallurgy Conf, on Specialty Metals Melting and Processing, Pittsburgh, PA. June 11-13, 1984.

(2) HERBERTSON J and HARRIS R., "Inclusion Removal by Hearth Refining" Proc. of the Conf. Electron Beam Meling and Refining - State of the Art 1985, Reno, Nevada, 1985.

(3) CHINNIS W.R and ESCHENBACH R.C., "Plasma Hearth Melting of Seeded Titanium" Proc. of the 1988 Vacuum Metallurgy Conf., San Diego, CA., 1988.

(4) SEARS J.W., "Clean Melting Techniques for the Production of Titanium Alloy Powders and Spray Deposits" Proc. of Advances in Powder Metallurgy, 1991, Chicago, IL, Vol. 6, pp 335-346.

(5) SEARS J.W, YOUNG J.M and KEARNS M., "The Effects of Plasma Cold-Hearth Melting on the Production of Titanium Alloy Ingots" Proc. Seventh World Conf. on Titanium, San Diego, CA, 1992.

(6) WARD R.M., "Plasma Melting; Intelligent Control Strategies" This Conference.

(7) SCHLIENGER M.E and MALLEY D.R., "Control Considerations in Cold-Hearth Withdrawal" Proc. of the Conf. Electron Beam Melting and Refining - State of the Art 1989. Reno, Nevada, 1989. 